\title{
Mosquito community composition in dynamic landscapes from the Atlantic Forest biome (Diptera, Culicidae)
}

\author{
Mário Luís Pessôa Guedes \& Mário Antônio Navarro-Silva
}

Departamento de Zoologia, Universidade Federal do Paraná, Caixa Postal 19020, 81531-980 Curitiba-PR, Brazil. pessoaguedes@gmail.com; mnavarro@ufpr.br

\begin{abstract}
Mosquito community composition in dynamic landscapes from the Atlantic Forest biome (Diptera, Culicidae). Considering that some species of Culicidae are vectors of pathogens, both the knowledge of the diversity of the mosquito fauna and how some environment factors influence in it, are important subjects. In order to address the composition of Culicidae species in a forest reserve in southern Atlantic Forest, we compared biotic and abiotic environmental determinants and how they were associated with the occurrence of species between sunset and sunrise. The level of conservation of the area was also considered. The investigation was carried out at Reserva Natural do Morro da Mina, in Antonina, state of Paraná, Brazil. We performed sixteen mosquito collections employing Shannon traps at three-hour intervals, from July 2008 to June 2009 . The characterization of the area was determined using ecological indices of diversity, evenness, dominance and similarity. We compared the frequency of specimens with abiotic variables, i.e., temperature, relative humidity and pluviosity. Seven thousand four hundred ten mosquito females were captured. They belong to 48 species of 12 genera. The most abundant genera were Anopheles, Culex, Coquillettidia, Aedes and Runchomyia. Among the species, the most abundant was Anopheles cruzii, the primary vector of Plasmodium spp. in the Atlantic Forest. Results of the analyses showed that the abiotic variables we tested did not influence the occurrence of species, although certain values suggested that there was an optimum range for the occurrence of culicid species. It was possible to detect the presence of species of Culicidae with different epidemiologic profiles and habitat preference.
\end{abstract}

KEYWORDS. Diversity; Insecta; malaria; Shannon trap; tropical rain forest.

Although the Brazilian Atlantic Forest has been classified as one of the five most important biodiversity hotspots on earth, it continues to be the target of anthropogenic activity (Myers et al. 2000). Even after centuries of destruction, however, this biome is still home to more than 8,000 endemic species of vascular plants, amphibians, reptiles, birds and mammals (Maack 1981; Ab'Saber 2003).

The Culicidae of the Atlantic Forest are represented by 23 genera and approximately 90 species (Forattini 2002; Harbach 2007; Guedes 2012). In the state of Paraná, there are 205 species of Culicidae of 18 genera. This corresponds to approximately $10 \%$ of the culicid fauna of the Neotropical Region (Lozovei \& Luz 1976; Lozovei 2001; Barbosa et al. 2003; Bona \& Navarro-Silva 2006; Guedes 2012; Müller et al. 2012).

In this study we addressed the composition of a culicid community that occurs in a forest reserve area situated in the southern Atlantic Forest of the state of Paraná. The region had been under intense human exploitation for natural resources. Mosquitoes present in the area have never been sampled. Additionally, we assessed the circadian and seasonal characteristics of the Culicidae community to address species occurrence patterns and to provide information for environmental conservation and entomological monitoring.

\section{MATERIAL AND METHODS}

Culicid adults were captured in sixteen field trips between July 2008 and June 2009 at the Atlantic Forest of the Reserva
Natural do Morro da Mina, in Antonina, state of Paraná, Brazil (Figs. 1-3). According to the Köppen's classification, the local climate is Af type (Köppen 1936).

The study area had been under intense ecological pressure caused by the exploitation of natural resources and unplanned extractivism. From 1930 to the mid-1980s there was extensive extraction of iron ore in the region. After that, trees were cut off for charcoal production. The area came under government protection in 1995 and is now under the administration of the Sociedade de Pesquisa em Vida Selvagem e Educação Ambiental (SPVS), which seeks to preserve and to regenerate the local forest (IAP 2013).

We used a Shannon trap (Shannon 1939) modified with a light source to capture females of Culicidae. One trap was installed about $50 \mathrm{~m}$ from the forest border into the forest $\left(25^{\circ} 22^{\prime} 54^{\prime \prime} \mathrm{S}, 48^{\circ} 47^{\prime} 03^{\prime \prime} \mathrm{W}\right)$. In order to avoid the intrusion effect we installed the traps one hour before we started collecting. Each sampling interval, equivalent to a total of nine hours, was divided into three phases, as following: evening twilight (one hour and a half before and one hour and a half after sunset), nocturnal (three hours between evening twilight and morning twilight) and morning twilight (one hour and a half before and one hour and a half after sunrise). Each three-hour phase was divided into intervals of thirty-minutes, in the end of which culicids were aspirated, totaling six captures in each phase.

The nomenclature and abbreviations adopted herein for all Culicidae genera and subgenera followed WRBU (2013) 


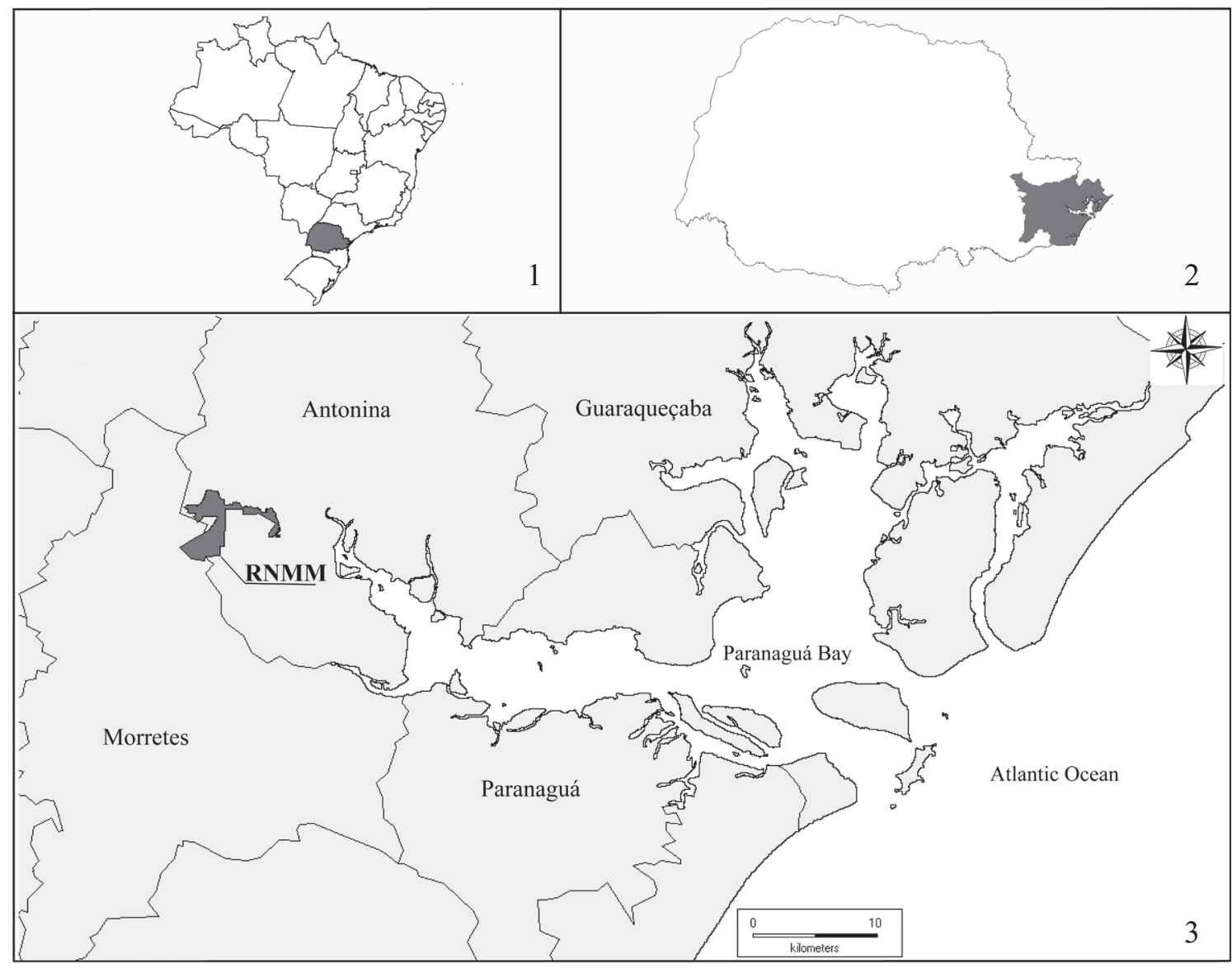

Figs. 1-3. Geographic location of the study site in southern Brazil. 1, Map of Brazil, with indication of the State of Paraná (in gray), 2, Map of the State of Paraná, with emphasis on the municipalities along the coast of the state. 3, Location of the study site, Reserva Natural do Morro da Mina (RNMM), in the coastal plain of the Paranaguá bay, in Paraná.

and Reinert (2001). Voucher specimens are deposited in the Coleção Entomológica Padre Jesus Santiago Moure (DZUP) of the Departamento de Zoologia at UFPR.

Pluviometric data are presented as the sum of two successive periods of collecting; in analyses, we used the maximum, minimum and the average values of temperature and relative humidity. The seasons were divided as follows: from June $21^{\text {st }}$ to September $23^{\text {rd }}$, winter (four collections); from September $23^{\text {rd }}$ to December $21^{\text {st }}$, spring (four collections); from December $21^{\text {st }}$ to March $21^{\text {st }}$, summer (four collections) and from March $21^{\text {st }}$ to June $21^{\text {st }}$, fall (four collections).

To describe the faunal composition we used the following ecological indices: evenness (Pielou - J'), dominance (BergerParker) and diversity (Shannon - H). Simple linear correlation tests were conducted to verify the existence of a possible interference of abiotic conditions on the numbers of Culicidae collected. For this we used the mean values and the sum of two collections of rainfall, temperature and relative humidity (since they are percentage values of relative humidity they were transformed into arcsine values to become comparable).

The computer program Paleontological Statistics Software Package for Education and Data Analysis version 1.88 (PAST) was used to analyze the data (Hammer et al. 2001).

\section{RESULTS}

The Shannon diversity index for the Culicidae was $\mathrm{H}=$ 1.5. This value reflects the 7,410 female specimens captured belonging to 12 genera and 48 species (Table I).

During the spring, a low equitability rate was detected (Table II). About $78 \%$ of the species and more than half of the number of individuals collected were recorded during this season, when Anopheles (Kerteszia) cruzii Dyar \& Knab, 1908 was very abundant. During the winter, the local species diversity was more elevated because a fewer number of individuals was collected. Fall was characterized by a higher evenness, whereas in the summer we observed a higher diversity and a lower species dominance (Table II).

Anopheles (Ker.) bellator Dyar \& Knab, 1906, An. (Ano.) intermedius (Peryassú, 1908), Li. flavisetosus de Oliveira Castro, 1935, Ru. (Run.) reversa (Lane \& Cerqueira, 1942) and Ru. (Run.) theobaldi (Lane \& Cerqueira, 1942) were collected throughout the year, whereas other species were rare, occurring in less than four samples: Anopheles (Nys.) evansae (Brethés, 1926), An. (Nys.) triannulatus (Neiva \& Pinto, 1922), Culex (Mel.) sacchettae Sirivanakarn \& Jakob, 1982, Cx. (Phe.) corniger Theobald, 1903, Wyeomyia (Pho.) galvaoi 
Table I. Species composition and abundance of Culicidae collected in the Reserva Natural do Morro da Mina, Paraná, southern Brazil, in the period of July 2008 to June 2009, with Shannon trap.

\begin{tabular}{|c|c|c|c|}
\hline Subfamily/Tribe & Species & Abundance & $\%$ \\
\hline \multirow[t]{8}{*}{ Anophelinae } & Anopheles (Anopheles) fluminensis Root, 1927 & 10 & 0.1 \\
\hline & Anopheles (Anopheles) intermedius (Peryassú, 1908) & 34 & 0.5 \\
\hline & Anopheles (Anopheles) mediopunctatus s.1. & 94 & 1.3 \\
\hline & Anopheles (Kerteszia) bellator Dyar \& Knab, 1906 & 60 & 0.8 \\
\hline & Anopheles (Kerteszia) cruzii Dyar \& Knab, 1908 & 4,924 & 66.5 \\
\hline & Anopheles (Kerteszia) sp. & 11 & 0.1 \\
\hline & Anopheles (Nyssorhynchus) evansae (Brethés, 1926) & 2 & 0 \\
\hline & Anopheles (Nyssorhynchus) triannulatus (Neiva \& Pinto, 1922) & 6 & 0.1 \\
\hline \multicolumn{4}{|l|}{ Culicinae } \\
\hline \multirow[t]{6}{*}{ Aedini } & Ochlerotatus (Ochlerotatus) scapularis (Rondani, 1848) & 102 & 1.4 \\
\hline & Ochlerotatus (Protoculex) aff. hastatus (Dyar, 1922) & 14 & 0.2 \\
\hline & Ochlerotatus (Protoculex) aff. serratus (Theobald, 1901) & 164 & 2.2 \\
\hline & Psorophora (Janthinosoma) champerico (Dyar \& Knab, 1906) & 2 & 0 \\
\hline & Psorophora (Janthinosoma) ferox (von Humboldt, 1819) & 16 & 0.2 \\
\hline & Psorophora (Janthinosoma) lutzii (Theobald, 1901) & 15 & 0.2 \\
\hline \multirow[t]{13}{*}{ Culicini } & Culex (Culex) aff. bidens Dyar,1922 & 304 & 4.1 \\
\hline & Culex (Culex) chidesteri Dyar, 1921 & 10 & 0.1 \\
\hline & Culex (Culex) coronator complex & 109 & 1.5 \\
\hline & Culex (Culex) aff. dolosus (Lynch Arribálzaga, 1891) & 38 & 0.5 \\
\hline & Culex (Culex) aff. maxi Dyar, 1928 & 3 & 0 \\
\hline & Culex (Culex) ssp. & 162 & 2.2 \\
\hline & Culex (Melanoconion) pedroi Sirivanakarn \& Belkin, 1980 & 2 & 0 \\
\hline & Culex (Melanoconion) aff. pedroi Sirivanakarn \& Belkin, 1980 & 2 & 0 \\
\hline & Culex (Melanoconion) ribeirensis Forattini \& Sallum, 1985 & 208 & 2.8 \\
\hline & Culex (Melanoconion) sacchettae Sirivanakarn \& Jakob, 1982 & 10 & 0.1 \\
\hline & Culex (Melanoconion) section of Melanoconion & 29 & 0.4 \\
\hline & Culex (Phenacomyia) corniger Theobald, 1903 & 15 & 0.2 \\
\hline & Lutzia (Lutzia) bigoti (Bellardi, 1862) & 4 & 0.1 \\
\hline \multirow[t]{5}{*}{ Mansoniini } & Coquillettidia (Rhynchotaenia) albicosta (Peryassú, 1908) & 636 & 8.6 \\
\hline & Coquillettidia (Rhynchotaenia) chrysonotum (Peryassú, 1922) & 48 & 0.6 \\
\hline & Coquillettidia (Rhynchotaenia) hermanoi (Lane \& Coutinho, 1940) & 165 & 2.2 \\
\hline & Coquillettidia (Rhynchotaenia) venezuelensis (Theobald, 1912) & 12 & 0.2 \\
\hline & Mansonia titillans (Walker, 1848) & 2 & 0.0 \\
\hline \multirow[t]{13}{*}{ Sabethini } & Limatus flavisetosus de Oliveira Castro, 1935 & 38 & 0.5 \\
\hline & Runchomyia (Runchomyia) reversa (Lane \& Cerqueira, 1942) & 49 & 0.7 \\
\hline & Runchomyia (Runchomyia) theobaldi (Lane \& Cerqueira, 1942) & 57 & 0.8 \\
\hline & Trichoprosopon pallidiventer (Lutz, 1905) & 1 & 0 \\
\hline & Wyeomyia (Menolepis) aff. leucostigma Lutz, 1904 & 3 & 0 \\
\hline & Wyeomyia (Phoniomyia) galvaoi (Corrêa \& Ramalho, 1956) & 7 & 0.1 \\
\hline & Wyeomyia (Phoniomyia) incaudata (Root, 1928) & 5 & 0.1 \\
\hline & Wyeomyia (Phoniomyia) pilicauda Root, 1928 & 2 & 0 \\
\hline & Wyeomyia (Phoniomyia) quasilongirostris (Theobald, 1907) & 5 & 0.1 \\
\hline & Wyeomyia (Phoniomyia) sp. & 1 & 0.0 \\
\hline & Wyeomyia (Prosopolepis) confusa (Lutz, 1905) & 22 & 0.3 \\
\hline & Wyeomyia (Spilonympha) aff. mystes Dyar, 1924 & 2 & 0 \\
\hline & Wyeomyia (subgenus uncertain) negrensis Gordon \& Evans, 1922 & 2 & 0 \\
\hline \multirow[t]{3}{*}{ Uranotaeniini } & Uranotaenia (Uranotaenia) geometrica Theobald, 1901 & 1 & 0 \\
\hline & Uranotaenia (Uranotaenia) aff. pallidoventer (Theobald, 1907) & 1 & 0 \\
\hline & Uranotaenia (Uranotaenia) lowii Theobald, 1901 & 1 & 0 \\
\hline Total & & 7,410 & 100 \\
\hline
\end{tabular}

(Corrêa \& Ramalho, 1956), Wy. (Pho.) incaudata Root, 1928 and Wy. (Pho.) quasilongirostris (Theobald, 1907).

Most individuals of Oc. scapularis (Rondani, 1848) were collected from August to December. Coquillettidia (Rhy.) hermanoi (Lane \& Coutinho, 1940) was captured in all seasons but was more frequent in September and October. Although occurring in lower frequency, Cq. (Rhy.) albicosta (Peryassú, 1908) had an expressive presence, peaking in December (Fig. 4). 
Specimens in the $C x$. $(C u x$.) coronator complex were more frequent from November to June, whereas $\mathrm{Cx}$. (Mel.) ribeirensis Forattini \& Sallum, 1985 was collected throughout the year, mainly during the last months of the spring. Anopheles mediopunctatus s.l. was captured during the spring. However, the species was found more frequently and in higher number from October to December (Fig. 4).

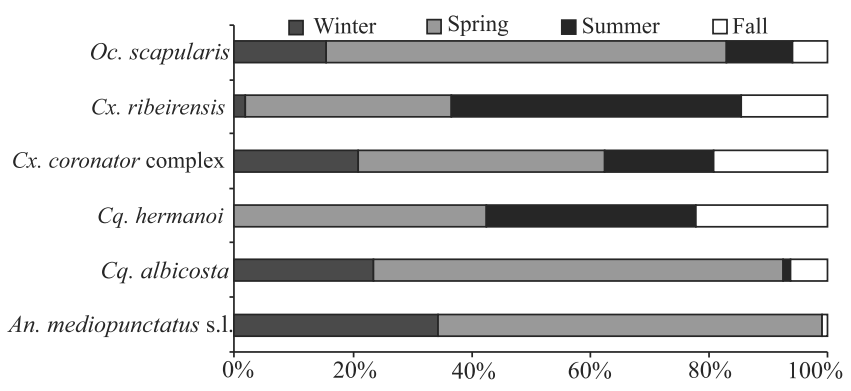

Fig. 4. Species of Culicidae with relative occurrence between $1 \%$ and $10 \%$ captured along the seasons in the Reserva Natural do Morro da Mina, Paraná, southern Brazil, in the period of July 2008 to June 2009.

Anopheles cruzii was the dominant species, representing $66 \%$ of total Culicidae captured. The greatest numbers of individuals were obtained in October $(\mathrm{n}=335)$, November $(\mathrm{n}=328)$ and December $(\mathrm{n}=1,940)$ (Fig. 5).

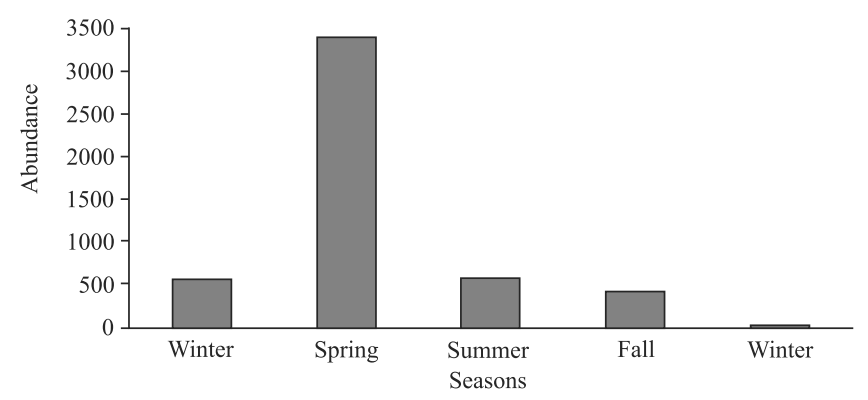

Fig. 5. Occurrence of Anopheles (Kerteszia) cruzii along the seasons from July 2008 to June 2009, in the Reserva Natural do Morro da Mina, Paraná, southern Brazil.

The mean precipitation and mean temperature, for the sum of two successive periods of collecting, during the twelve months of the study (July 2008 to June 2009) were $6.1 \mathrm{~mm}$ $( \pm 11.4)$ and $20^{\circ} \mathrm{C}( \pm 3.4)$, respectively. The highest mean temperatures were recorded in March $\left(29^{\circ} \mathrm{C}\right)$, May $\left(31^{\circ} \mathrm{C}\right)$ and July $\left(29^{\circ} \mathrm{C}\right)$, whereas the highest temperature range $\left( \pm 19.4^{\circ} \mathrm{C}\right)$ was found in July. The average relative humidity during the period of the collections was $90 \%( \pm 5.78)$.

The results of linear regression analyses did not reveal a significant correlation between the number of mosquitoes and the following daily or monthly average variables: temperature, precipitation and relative humidity.

The highest richness and the greatest numbers of individuals were detected in the evening twilight, when 33 species and about 3,700 individuals were obtained. The ecological indices depicted an increased ecological diversity and evenness of species over the three time slots and a reduction in species dominance from the dusk to the morning (Table II).

Table II. Ecological indices applied to the species of Culicidae sampled during the seasons and to the species captured at different sampling times in the Reserva Natural do Morro da Mina, Paraná, southern Brazil, in the period of July 2008 to June 2009.

\begin{tabular}{|c|c|c|c|c|c|c|c|}
\hline \multirow[b]{2}{*}{ Index } & \multicolumn{4}{|c|}{ Season } & \multicolumn{3}{|c|}{ Intervals } \\
\hline & Winter & Spring & Summer & Fall & $\mathrm{CV}$ & IN & $\mathrm{CM}$ \\
\hline Shannon $(H)$ & 1.21 & 0.81 & 1.16 & 1.31 & 1.41 & 1.44 & 2.03 \\
\hline Berger-Parker & 0.65 & 0.78 & 0.49 & 0.52 & 0.71 & 0.64 & 0.51 \\
\hline Pielou (J') & 0.55 & 0.33 & 0.50 & 0.57 & 0.37 & 0.44 & 0.58 \\
\hline
\end{tabular}

Sabethini (Limatus, Runchomyia and Trichoprosopon) were not collected during the night. Specimens of Mansonia were captured only in the morning twilight and the species of the genus Uranotaenia were not recorded in this interval. The following species of Culex were more common in the evening twilight: An. (Ker.) bellator, An. (Ano.) intermedius, Cq. (Rhy.) chrysonotum (Peryassú, 1922) and Ps. (Jan.) ferox (von Humboldt, 1819). The two species of Runchomyia, Ru. (Run.) reversa (Lane \& Cerqueira, 1942), Ru. (Run.) theobaldi (Lane \& Cerqueira, 1942) and Li. flavisetosus, Ps. (Jan.) champerico (Dyar \& Knab, 1906), Ps. (Jan.) lutzii (Theobald, 1901) were captured during morning and evening twilights. Anopheles (Nys.) triannulatus, Tr. pallidiventer (Lutz, 1905), Uranotaenia (Ura.) geometrica Theobald, 1901, Ur. (Ura.) lowii Theobald, 1901, Wyeomyia (Pho.) galvaoi, and Wy. (Pho.) quadrilongirostris were captured only in the evening twilight, whereas Ma. titillans (Walker, 1848) and An. evansae only in the morning twilight.

Anopheles mediopunctatus s.l. and Cq. (Rhy.) hermanoi are characterized as species that occur in the evening twilight, because $60 \%$ of the specimens were collected during that period. Species of the Cx. coronator complex are active at dusk and continue overnight. The activity period of Ochlerotatus (Och.) scapularis was constant during the intervals sampled (Fig. 6). Anopheles (Ker.) cruzii was captured in large number during the evening twilight, whereas Cx. (Mel.) ribeirensis and Cq. (Rhy.) albicosta were more frequent overnight (Fig. 6).

Because An. (Ker.) cruzii was found in great number and that $58 \%$ of the specimens were captured in the evening twilight (Fig. 7), we were able to address its activity pattern during the 9-hour period of Shannon collections. Accordingly, frequencies of specimens obtained in each 30-minute collection intervals were analyzed separate. Based on the time of sunset, An. cruzii is an eocrepuscular species (Fig. 8), peaking immediately after dusk. During the night (Fig. 9) the average number of mosquitoes was approximately 200 specimens collected every 30 minutes, decreasing during the twilight (Fig. 10). The frequency of An. cruzii was higher at the sunset (evening twilight-interval $\mathrm{p}=0.183, \mathrm{r}=0.625$ ) than at sunrise (morning twilight interval $\mathrm{p}=0.019, \mathrm{r}=0.882$ ). 


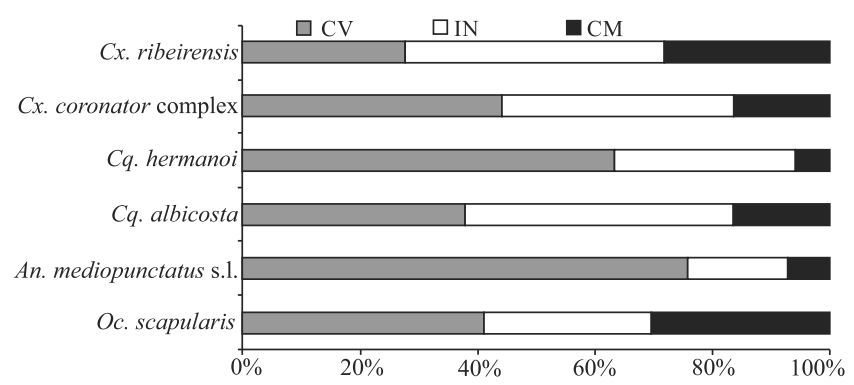

Fig. 6. Species of Culicidae with relative occurrence between $1 \%$ and $10 \%$ of Culicidae captured in each interval (CV-evening twilight interval; IN-night interval; CM-morning twilight interval), in the Reserva Natural do Morro da Mina, Paraná, southern Brazil, in the period of July 2008 to June 2009.

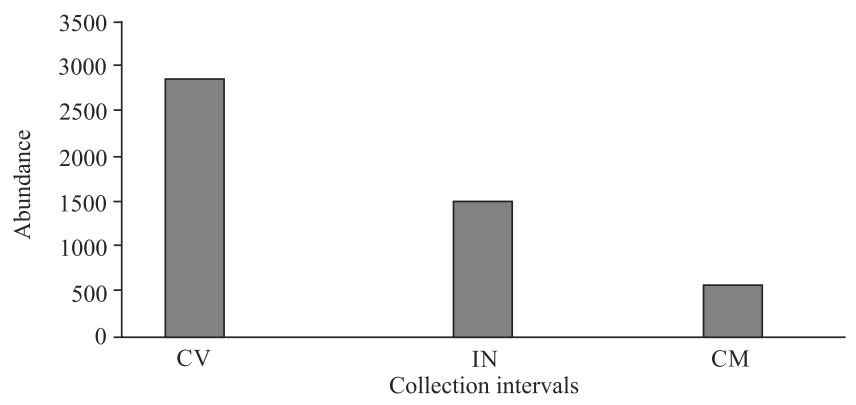

Fig. 7. Occurrence of Anopheles (Kerteszia) cruzii in the three collection intervals, (CV) Evening twilight interval, (IN) night interval, (CM) morning twilight interval, in the Reserva Natural do Morro da Mina, Paraná, southern Brazil, in the period of July 2008 to June 2009.

\section{DISCUSSION}

The floristic and the faunal composition of the Reserva Natural do Morro da Mina has characteristics that can potentially support a diverse community of Culicidae, providing distinct larval habitats, for instance, phytotelmatas, and several blood sources, such as birds and mammals (IPARDES 1990).

Studies conducted in different areas of the Atlantic Forest biome in the state of Paraná recorded 25 (Bona \& NavarroSilva 2008) and 31 (Santos Neto \& Lozovei 2008) species of Culicidae. Despite the different sampling designs used, $A n$. cruzii was dominant in both studies: $40 \%$ and $50 \%$ of the total samples, respectively. Even when the environment is conducive to the development of culicid species, the temporal dynamics of these organisms may be influenced by the length of the days and nights (Day 2005; Nagm et al.2007). In this study, we found that An. mediopunctatus s.l. and Cq. hermanoi are active in the evening twilight, whereas $C x$. ribeirensis and $C q$. albicosta are mostly active at night.

The temporal patterns, when analyzed at different scales, differ among species (circadian oscillations and seasonal variations) (Bradshaw et al. 2004). The occurrence of An. cruzii was high in all three intervals, indicating activity mostly in the evening twilight and potential activity throughout the evening, suggesting that the decreased brightness is one factor that in-
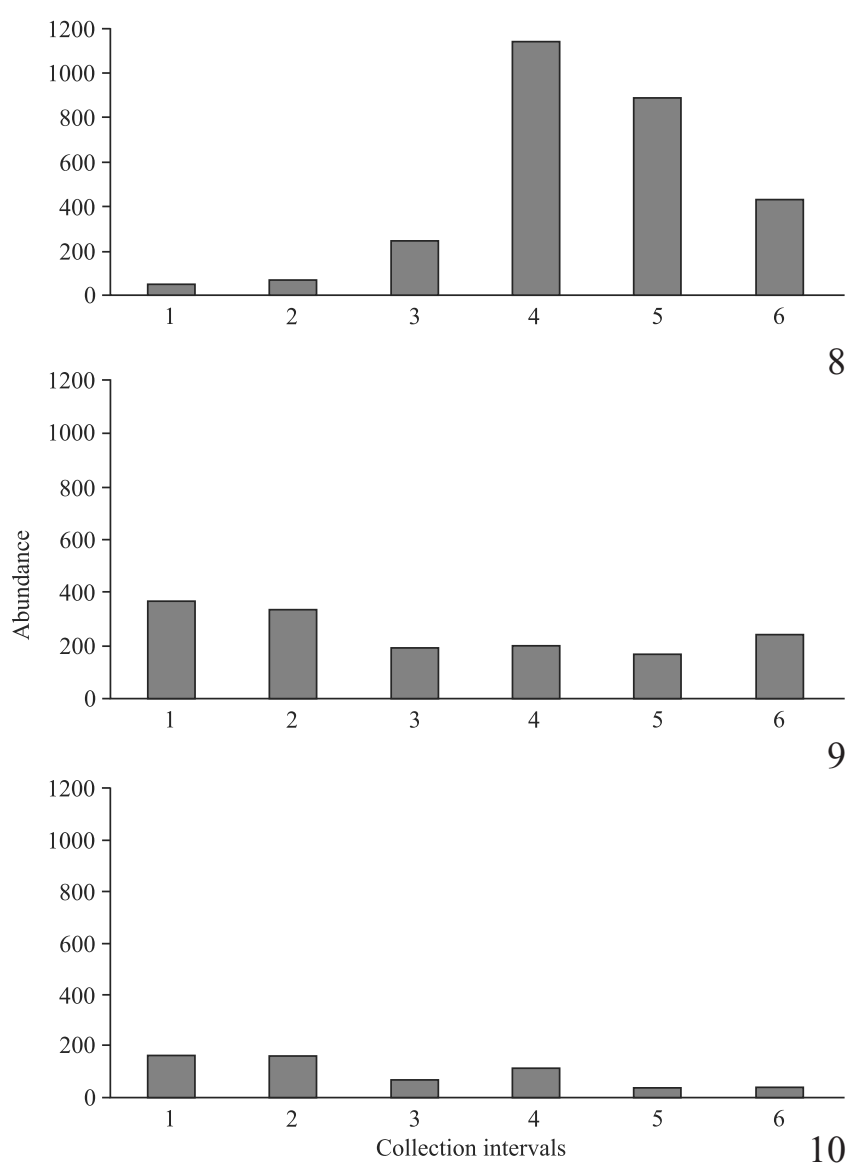

Figs. 8-10. Occurrence of Anopheles (Kerteszia) cruzii in collection intervals divided into six phases of thirty-minutes each, in the Reserva Natural do Morro da Mina, Paraná, southern Brazil, in the period of July 2008 to June 2009. 8, Evening twilight interval (numbers 3 and 4 are related to the time of evening twilight). 9, Night interval. 10, Morning twilight interval (numbers 3 and 4 are related to the time of morning twilight).

fluences the circadian rhythm of activity of this insect. It is known that this species can also occur during the morning in forested areas with similar floristic composition (Veloso et al. 1956; Aragão 1974; Bona \& Navarro-Silva 2006).

Particularly in the southern and southeastern coastal area of Brazil the seasonal behavior of An. cruzii is somewhat well known and there may be some monthly and seasonal changes in its abundance (Forattini et al.1968; Forattini et al. 1986; Guimarães et al. 2000). Usually, culicid species are more abundant when temperature and precipitation values are greater, which in the Atlantic Forest occurs in the summer (Guimarães et al. 2001; Rona et al. 2009). However, in the present study, An. cruzii was more abundant in the spring, indicating that the seasonal pattern previously mentioned can change depending on the variations in the biotic and abiotic factors.

Culex ribeirensis occurs in regions adjacent to the coastal plains and slopes of the Atlantic rainforest (Forattini \& Sallum 1985). This species has nocturnal activity and is commonly caught in automatic light traps (Forattini et al. 1991, SantosNeto \& Lozovei 2008). Its occurrence is associated to the pluviometric precipitation since the immature stages were 
found in ground pool habitats where rainwater can accumulate (Forattini 2002).

The low abundance of representatives of the Sabethini in the present study may be due to the fact that most species are diurnal, peaking during the day (Lane \& Cerqueira 1942). Diurnal collections were conducted in two periods of $1 \mathrm{~h} 30$ minutes before and after sunrise. Moreover, a high richness of species of Sabethini may reflect a preserved environment (Dorvillé 1996), because the ecological characteristics present in preserved forest areas favor the occurrence of larval habitats and environmental conditions for the establishment of a diverse assemblage of species. The area occupied by the Reserva Natural Morro da Mina was under intensive ecological transformation caused by human activities, which included deforestation and mineral resources exploitation. Currently, the reserve is at a secondary stage of ecological succession (Cheung et al. 2009), supporting a floristic composition that may provide habitats for a less diverse community of Sabethini.

Some species of one of the subgenera with relevant epidemiological significance, Culex (Culex) are favored by anthropogenic environmental changes (Forattini et al.1990; Lopes \& Lozovei 1995; Silva 2002; Alfonso et al. 2005). In our data, species in this subgenus occurred throughout the year, indicating that they were not influenced by the climatic factors utilized in the analyses.

In the lowland Atlantic Forest biome, periods marked by extremes in temperature and rainfalls do not occur over the different seasonal periods, providing suitable conditions for maintaining populations of Culicidae. The reduced range of environmental factors may favor the dominance of few species in different seasonal periods, as observed for An. cruzii (Tubaki et al. 1993; Guimarães et al. 2001).

During the evening twilight, species of Psorophora, Anopheles and Coquillettidia were predominant, whereas members of the tribe Sabethini were detected in low numbers, for instance Wyeomyia confusa (Lutz, 1905), Wy. galvaoi, Wy. pilicauda Root, 1928 and Wy. quasilongirostris. These species are diurnal (Lane \& Cerqueira 1942) and their activities were extended beyond the expected.

Mosquito vector species of human pathogens are present in the studied area. The most important pathogens and their potential mosquito vectors found in our collections are: Plasmodium spp. (An. cruzii), arboviruses (Oc. scapularis, Cx. ribeirensis and Ps. ferox) (Casanova \& Prado 2002; Guedes 2012). These mosquitoes, present in the forest, can acquire pathogens from sylvatic intermediate hosts and transmit them to humans when feeding on their blood (Reiter 2001; Lafferty 2009). Consequently, some mosquito species present in southern Atlantic Forest may participate of epidemiological cycles of reemergence of vector-borne diseases, which are mainly associated with environmental and climatic changes, as well as habitat fragmentation.

Despite the limitations of the mosquito sampling methods that were adopted in the study, we were capable of collecting more than $50 \%$ of the species that occur in the Atlantic Forest.
They represent approximately $30 \%$ of the species of Culicidae already found in the state of Paraná (Guedes 2012). It is necessary to stress the presence, frequency and dominance of $A n$. cruzii in the forest reserve area. The biological characteristics of this species, coupled with environmental and climatic changes, and also habitat fragmentation, may create new epidemiological scenarios of vector-borne diseases in the area, which justifies a constant entomological surveillance.

\section{ACKNOWLEDGMENTS}

We would like to offer our special thanks to the Sociedade de Pesquisa em Vida Selvagem e Educação Ambiental (SPVS), the Instituto Tecnológico SIMEPAR, CAPES and the Entomological Collection Pe. Jesus Santiago Moure (DZUP-UFPR) for the logistic support. We would like also to thank Dr. Allan Martins da Silva, Dr. Delsio Natal, Dr. Mauricio O. Moura, Dr. José Marcelo R. Aranha, Dr. Rosana M. Rocha, Msc. Camila Fediuk de Castro Guedes and Msc. Betina Westphal for their valuable and constructive suggestions during the development of this manuscript.

\section{REFERENCES}

Ab'Sáber, A. 2003. Os Domínios de Natureza no Brasil: Potencialidades Paisagísticas. $2^{\text {nd }} E d$. São Paulo, Ateliê Editora, 159 p.

Alfonso, D., Grillet, M.E., Liria, J., Navarro, J., Weaver, S.C. \& Barrera, R. 2005. Ecological characterization of the aquatic habitats of mosquitoes (Diptera: Culicidae) in enzootic foci of Venezuelan equine encephalitis virus in western Venezuela. Journal of Medical Entomology 42: 278-284.

Aragão, M.B. 1974. O comportamento dos anofelinos do subgênero Kerteszia no sul do Brasil e o efeito do inseticida DDT. Memórias do Instituto Oswaldo Cruz 72: 147-172.

Barbosa, A.A., Navarro-Silva, M.A. \& Calado, D. 2003. Atividade de Culicidae em remanescente florestal na região urbana de Curitiba (Paraná, Brasil). Revista Brasileira de Zoologia 20: 59-63.

Bona, A.C.D. \& Navarro-Silva, M.A. 2006. Paridade de Anopheles cruzii em floresta ombrófila densa no sul do Brasil. Revista de Saúde Pública 40: $1118-23$.

Bradshaw, W.E., Zani, P.A. \& Holzapfel, C.M. 2004. Adaptation to temperate climates. Evolution 58: 1748-1762.

Bona, A.C.D. \& Navarro-Silva, M.A. 2008. Diversidade de Culicidae durante os períodos crepusculares em bioma de Floresta Atlântica e paridade de Anopheles cruzii (Diptera: Culicidae). Revista Brasileira de Zoologia 25: 40-48.

Casanova, C. \& Prado, A.P. 2002. Key-factor analysis of immature stages of Aedes scapularis (Diptera, Culicidae) populations in southeastern Brazil. Bulletin of Entomological Research 92: 271-277.

Cheung, K.C., Marques, M.C.M. \& Liebsch, D. 2009. Relação entre a presença de vegetação herbácea e a regeneração natural de espécies lenhosas em pastagens abandonadas na Floresta Ombrófila Densa do Sul do Brasil. Acta Botanica Brasilica 23: 1048-1056.

Day, J.E. 2005. Host-seeking strategies of mosquito disease vectors. Journal of the American Mosquito Control Association 21: 17-22.

Dorvillé, L.F.M. 1996. Mosquitoes as bioindicators of forest degradation in southeastern Brazil, a statistical evaluation of published data in the literature. Studies on Neotropical Fauna and Environment 31: 68-78.

Forattini, O P. 2002. Culicidologia Médica. Vol. 2. São Paulo, EDUSP, $864 \mathrm{p}$.

Forattini, O.P. \& Sallum, M.A.M. 1985. A new species of Culex (Melanoconion) from southern Brazil (Diptera: Culicidae). Revista de Saúde Pública 19: $171-182$. 
Forattini, O.P., Gomes, A.C., Kakitani, I. \& Marucci, D. 1991. Observações sobre domiciliação de mosquitos Culex (Melanoconion) em ambiente com acentuadas modificações antrópicas. Revista de Saúde Pública 25: 257-66.

Forattini, O.P., Alves, A.C., Natal, D. \& Santos, J.L.F. 1986. Observações sobre atividade de mosquitos Culicidae em mata primitiva da encosta no Vale do Ribeira, São Paulo, Brasil. Revista de Saúde Pública 20: $1-20$.

Forattini, O.P., Gomes, A.C., Santos, J.L.F., Kakitani, I. \& Marucci, D. 1990. Frequência ao ambiente humano e dispersão de mosquitos Culicidae em área adjacente à mata Atlântica primitiva da planície. Revista de Saúde Pública 24: 101-107.

Forattini, O.P., Lopes, O.S. \& Rabello, E.X. 1968. Investigações sobre o comportamento de formas adultas de mosquitos silvestres no Estado de São Paulo, Brasil. Revista de Saúde Pública 2: 177-173.

Guedes, M.L.P. 2012. Culicidae (Diptera) no Brasil: relações entre enfermidades, distribuição e enfermidades. Oecologia Australis 16: $283-$ 296.

Guimarães, A.E., Gentile, C., Lopes, C.M. \& Sant'Anna, A. 2001. Ecologia de mosquitos em áreas do Parque Nacional da Serra da Bocaína. II Frequência mensal e fatores climáticos. Revista de Saúde Publica 35 : 392-399.

Guimarães, A.E., Mello, R.P., Lopes, C.M. \& Gentile, C. 2000. Ecology of mosquitoes (Diptera: Culicidae) in areas of Serra do Mar State Park, State of São Paulo, Brazil. I - monthly frequency and climatic factors. Memórias do Instituto Oswaldo Cruz 95: 1-16.

Hammer, Ø., Harper, D.A.T. \& Ryan, P.D. 2001. PAST: Paleontological statistics software package for education and data analysis. Paleontologia Electronica 4: 9.

Harbach, R.E. 2007. The Culicidae (Diptera): a review of taxonomy, classification and phylogeny. Zootaxa 1668: 591-638.

IAP (Instituto ambiental do Paraná). 2013. Plano de Manejo RPPN Morro da Mina e Santa Maria. Available at: www.iap.pr.gov.br (accessed 13 September 2013).

IPARDES (Instituto Paranaense de Desenvolvimento Econômico e Social \& Instituto Brasileiro do Meio Ambiente e dos Recursos Naturais Renováveis). 1990. Macrozoneamanto da APA de Guaraqueçaba. Curitiba, vol.1, $54 \mathrm{p}$.

Köppen, W. 1936. Das geographische System der Klimate. Handbuch der Klimatologie 1: 44.

Lafferty, K.D. 2009. The ecology of climate change and infectious diseases. Ecology 90: 888-900.

Lane, J. \& Cerqueira, N.L. 1942. Os sabetíneos da América (Diptera, Culicidae). Arquivos de Zoologia do Estado de São Paulo 3: 473-849.

Lopes, J. \& Lozovei, A.L. 1995. Ecologia de mosquitos (Diptera: Culicidae) em criadouros naturais e artificiais de área rural do norte do Estado do Paraná, Brasil. I - coletas ao longo do leito de ribeirão. Revista de Saúde Pública 29: 183-191.
Lozovei, A.L. 2001. Microhabitats de mosquitos (Diptera, Culicidae) em internódios de taquara na Mata Atlântica, Paraná, Brasil. Iheringia, Série Zoologia, 90: 3-13.

Lozovei, A.L. \& Luz, E. 1976. Diptera, Culicidae em Curitiba e arredores - I ocorrência. Arquivos de Biologia e Tecnologia 19: 25-42.

Maack, R. 1981. Geografia Física do Estado do Paraná. Rio de Janeiro, Livraria José Olympio Ed., 442 p.

Myers, N., Mittermeier, R.A., Mittermeier, C.G., Fonseca, G.A.B. \& Kent, J. 2000. Biodiversity hotspots for conservation priorities. Nature 403: $853-858$.

Müller, G.A., Bona, A.C.D., Marcondes, C.B. \& Navarro-Silva, M.A. 2012. Crepuscular activity of culicids (Diptera, Culicidae) in the peridomicile and in the remaining riparian forest in Tibagi river, State of Paraná, Brazil. Revista Brasileira de Entomologia 56: 111-114.

Nagm, L., Luitgard-Moura, J.F., Neucamp, C.S., Monteiro-de-Barros, F.S., Honório, N.A., Tsouris, P. \& Rorsa-Freitas, M.G. 2007. Affinity and diversity indices for anopheline immature forms. Revista do Instituto de Medicina Tropical 49: 309-316.

Reinert, J.F. 2001. Revised list of abbreviations for genera and subgenera of Culicidae (Diptera) and notes on generic and subgeneric changes. Journal of the American Mosquito Control Association 17: 51-55.

Reiter, P. 2001. Climate change and mosquito-borne disease. Environmental Health Perspectives 109: 141-161.

Rona, L.D.P., Carvalho-Pinto, C.J., Gentile, C., Grissard, E.C. \& Peixoto, A.A. 2009. Assessing the molecular divergence between Anopheles (Kerteszia) cruzii populations from Brazil using the timeless gene: further evidence of a species complex. Malaria Journal 8: 1-10.

Santos-Neto, L.G. \& Lozovei, A.L. 2008. Aspectos ecológicos de Anopheles cruzii e Culex ribeirensis (Diptera, Culicidae) da Mata Atlântica de Morretes, Paraná, Brasil. Revista Brasileira de Entomologia 52: 105-111.

Shannon, R.C. 1939. Methods for collecting and feeding mosquitoes in jungle yellow fever studies. American Journal of Tropical Medicine and Hygiene 19: 131-140.

Silva, A.M. 2002. Imaturos de mosquitos (Diptera, Culicidae) de áreas urbana e rural no norte do Estado do Paraná, Brasil. Iheringia, Série Zoologia, 92: 31-36.

Tubaki, R.M., Carréri-Bruno, G.C., Glasser, C.M. \& Ciaravolo, R.M.C. 1993. Biting activity of Anopheles (Kerteszia) cruzii (Diptera, Culicidae) in domiciliary habitats in the southern Atlantic Forest, Peruibe, State of Sao Paulo, Brazil. Revista Brasileira de Entomologia 37: 569-575.

Veloso, H. P., Moura, J.V. \& Klein, R.M. 1956. Delimitação ecológica dos anofelíneos do subgênero Kerteszia na região costeira do sul do Brasil. Memórias do Instituto Oswaldo Cruz 54: 517-48.

WRBU (The Walter Reed Biosystematics Unit). 2013. New Mosquito Classification. Available at: http://www.wrbu.org/mq_NewClass201309. html (accessed 30 September 2013). 